\title{
Pengaruh Ekspor, Pengeluaran Pemerintah, dan Angkatan Kerja yang Bekerja Terhadap Pertumbuhan Ekonomi di Kabupaten Tulungagung
}

\author{
Endang Triwidyati ${ }^{1}$ \\ Nining Purnamaningsih ${ }^{2}$ \\ Universitas Kadiri - Kediri \\ endang_triwidyati@unik-kediri.ac.id \\ niningpurnamaningsih@unik-kediri.ac.id
}

\begin{abstract}
"Changes in the average value of economic activity from one year to another by taking the average at the same time" is a brief definition of economic growth. This study aims to determine the effect of exports, government spending and labor force working on economic growth in Tulungagung. The type of data used in this study are secondary data on exports, government spending and labor force working in 2008-2017 in the form of quantitative time series, with multiple linear analysis and classical assumption tests as data analysis methods. The results showed that (1) there was no significant positive effect of exports on Tulungagung's economic growth. (2) The effect of government spending on economic growth in Tulungagung is significantly positive. (3) The effect of the labor force working on economic growth from Tulungagung is positive insignificant.
\end{abstract}

Keywords : exports, government spending, labor force employed, economic growth

\begin{abstract}
ABSTRAK
"Perubahan nilai rata-rata dari kegiatan ekonomi dari tahun untuk satu periode ke periode yang lain dengan mengambil rata-ratanya dalam waktu yang sama" adalah definisi singkat dari pertumbuhan ekonomi. Penelitian ini bertujuan untuk mengetahui pengaruh ekspor, pengeluaran pemerintah dan angkatan kerja yang bekerja terhadap pertumbuhan ekonomi di Tulungagung. Jenis data yang digunakan dalam penelitian ini adalah data sekunder ekspor, pengeluaran pemerintah dan angkatan kerja yang bekerja pada tahun 2008-2017 dalam bentuk time series yang bersifat kuantitatif, dengan analisis linier berganda dan uji asumsi klasik sebagai metode analisis data. Hasil penelitian menunjukkan bahwa (1) tidak ada pengaruh positif yang signifikan dari ekspor terhadap pertumbuhan ekonomi Tulungagung. (2) Efek dari belanja pemerintah terhadap pertumbuhan ekonomi di Tulungagung positif signifikan. (3) Efek dari angkatan kerja yang bekerja dalam pertumbuhan ekonomi dari Tulungagung positif tidak signifikan.
\end{abstract}

Kata kunci: ekspor, pengeluaran pemerintah, angkatan kerja yang bekerja, pertumbuhan ekonomi. 


\section{PENDAHULUAN}

"Perubahan nilai rata-rata dari kegiatan ekonomi dari tahun untuk satu periode ke periode yang lain dengan mengambil rata-ratanya dalam waktu yang sama" adalah definisi singkat dari pertumbuhan ekonomi (economic growth). Dalam definisi ini, tingkat pendapatan nasional setiap tahun, harus menjadi salah satu basis perbandingan untuk mengatakan laju pertumbuhan ekonomi. Kota kediri merupakan salah satu dijawa timur yang memiliki aset wisata yang cukup potensial untuk dikembangkan bidang unggulan wisata kota kediri yaitu kuliner dan kerajinan juga kesenian jaranan (Dewandaru bothy, 2016). Penelitian mengenai teknologi yang sangat kurang dalam menjalankan usaha, minimnya pemanfaatan internet dalam mengelola usaha (Putra, Yudiarto Perdana, heryanto, 2017).

Sebagai bagian dari upaya untuk mencapai pertumbuhan ekonomi, pemerintah daerah dan masyarakat harus kompak dalam kegiatan pembangunan daerah. Efektivitas mengurangi jumlah penduduk miskin adalah pertumbuhan utama dalam memilih strategi atau instrument pembangunan. Dari hasil pembahasan di atas maka ditarik kesimpilan hasil analisa LQ menunjukkan kota padang merupakan daerah yang memiliki sektor basis 6 ,kabupaten memiliki basis sedikit namun pengembangan sektor unggulan hendaknya tidak mengabaikan sektor-sektor ekonomi lainya yang masih mempunyai kemungkinan untuk berkembang di masa yang akan datang. (Joan Marta, 2010). Berdasarkan hasil analisa regresi panel menggunakan coomoon efect model .pembahasan terhadap hasil penelitian antara variabel bebas terhadap variabel terikat (Endang Putri Dewi, 2019)

Berdasarkan pada konsep ekonomi terbuka, dimana "pertumbuhan ekonomi merupakan agregat dari konsumsi sektor rumah tangga, investasi, pengeluaran sektor pemerintah, dan perdagangan luar negeri sektor ekspor-impor ( $\mathrm{Y}=\mathrm{C}+\mathrm{I}+\mathrm{G}+\mathrm{NX})$ ". Perkembangan konsep oleh Keynes dan Harold-Domar ini yang menjadi dasar acuan penulis untuk mengembangkan dan meneliti pengaruh indikator-indikator ekonomi makro tersebut terhadap pertumbuhan ekonomi di Kabupaten Tulungagung. Penulis akan mencoba menggantikan variabel lain yang tidak digunakan dalam penelitian ini menggunakan variabel dari angkatan kerja. 
Tulungagung memiliki sumber daya daerah yang kaya dan potensial dan merupakan kabupaten terbesar dari Jawa Timur. Di bawah ini adalah perbandingan data pertumbuhan ekonomi Kabupaten Tulungagung dan provinsi Jawa Timur selama periode antara tahun 2017 pada tahun 2013.

Tabel 1 : Perbandingan Pertumbuhan Ekonomi Kabupaten Tulungagung dengan Pertumbuhan Provinsi Jawa Timur Tahun 2013-2017

\begin{tabular}{|c|c|c|}
\hline Tahun & $\begin{array}{c}\text { Pertumbuhan Ekonomi } \\
\text { Tulungagung (\%) }\end{array}$ & $\begin{array}{c}\text { Pertumbuhan Ekonomi } \\
\text { Provinsi Jawa Timur (\%) }\end{array}$ \\
\hline 2013 & 6.13 & 5.56 \\
\hline 2014 & 5.46 & 5.02 \\
\hline 2015 & 4.99 & 4.79 \\
\hline 2016 & 5.02 & 5.02 \\
\hline 2017 & 5.08 & 5.45 \\
\hline
\end{tabular}

Sumber: Data diolah peneliti, (2019).

Tabel di atas menunjukkan pertumbuhan ekonomi Tulungagung adalah menurun, kecuali pada tahun 2016. Dibandingkan dengan pertumbuhan pada tahun 2015, di tahun 2016 mengalami pertumbuhan sebesar 5,02\%, dari yang digambarkan oleh PDRB atas dasar harga konstan di tahun 2010. Hal ini karena sebagian besar sektor usaha / industri juga meningkat karena mengalami pertumbuhan yang baik. Namun, pertumbuhan ekonomi Kabupaten Tulungagung ada di atas pertumbuhan rata-rata di provinsi Jawa Timur.

\section{Tujuan Penelitian}

Tujuan penelitian untuk dicapai dalam perumusan masalah di atas adalah:

1. Untuk mendeskripsikan Efek Ekspor pada Pertumbuhan Ekonomi di Tulungagung.

2. Untuk menjelaskan Pengaruh pengeluaran pemerintah terhadap pertumbuhan ekonomi di Kabupaten Tulungagung.

3. Untuk menganalisa pengaruh Angkatan Kerja yang Bekerja terhadap Pertumbuhan Ekonomi di Kabupaten Tulungagung.

\section{TINJAUAN PUSTAKA}

\section{Pertumbuhan Ekonomi}

Pertumbuhan ekonomi merupakan indikator penting untuk analisis perkembangan ekonomi yang terjadi di negara ini. Pertumbuhan ekonomi menurut Arsyad (2014: 45) 
meningkatnya produk domestik bruto/produk nasional bruto, terlepas dari apakah laju peningkatan itu lebih besar/kecil dari pertumbuhan penduduk, apakah ada perubahan struktur ekonomi. Menurut Boediono (2014:41), pertumbuhan ini adalah kenaikan jangka panjang keluaran per kapita.

Menurut Biro Pusat Statistik, PDRB adalah total nilai barang dan jasa yang dihasilkan oleh seluruh unit usaha dalam suatu daerah tertentu. PDRB didefinisikan sebagai total nilai jasa dan barang yang dihasilkan dari semua unit ekonomi. Pertumbuhan ekonomi menunjukkan evolusi kegiatan ekonomi di wilayah tersebut. pertumbuhan ekonomi yang lebih tinggi di wilayah ini menunjukkan perkembangan kegiatan ekonomi.

Untuk menghitung laju pertumbuhan ekonomi adalah dengan menggunakan rumus sebagai berikut:

$$
\mathrm{Gt}=\frac{\mathrm{Y}_{\mathrm{t}}-\mathrm{Y}_{\mathrm{t}}-1}{\mathrm{Y}_{\mathrm{t}}-1} \times 100 \%
$$

Dimana:

$\mathrm{G}_{\mathrm{t}}=$ Pertumbuhan Ekonomi periode $\mathrm{t}$ (triwulan atau tahunan)

Yt = Produk Domestik Regional Bruto tahun sekarang

Yt-1 = Produk Domestik Regional Bruto tahun sebelumnya

Untuk menghitung pendapatan suatu negara atau wilayah, ada tiga cara yaitu menggunakan metode berikut:

1. Pendekatan produksi (Production Approach)

Ini dihitung dengan menambahkan nilai dari sektor-sektor produktif ekonomi untuk membuat produksi di wilayah negara. Secara matematis:

$$
\mathrm{NI}=\mathrm{P}_{1} \mathrm{Q}_{1}+\mathrm{P}_{2} \mathrm{Q}_{2}+\ldots+\mathrm{P}_{\mathrm{n}} \mathrm{Q}_{\mathrm{n}}
$$

dimana:

NI $=$ PDB (Produk Domestik Bruto)

$\mathrm{P}_{1}, \mathrm{P}_{2}, \ldots, \mathrm{P}_{\mathrm{n}}=$ Harga satuan produk pada satuan masing-masing sektor ekonomi

$\mathrm{Q}_{1}, \mathrm{Q}_{2}, \ldots, \mathrm{Q}_{\mathrm{n}}=$ Jumlah produk pada satuan masing-masing sektor ekonomi.

Perhitungan hanya menggunakan nilai tambah bruto saja agar terhindar dari perhitungan ganda.

2. Pendekatan Pendapatan (Income Approach) 
Metode ini menjumlah besar total pendapatan atau balas jasa setiap faktor-faktor produksi. Secara matematis:

$$
\mathrm{Y}=\mathrm{Yw}+\mathrm{Yr}+\mathrm{Yi}+\mathrm{Yp}
$$

dimana:

$\mathrm{Y}=$ Pendapatan nasional atau PDB

Yw = Pendapatan upah/gaji

Yr = Pendapatan sewa

$\mathrm{Yi}=$ Pendapatan bunga

Yp = Pendapatan laba atau profit.

3. Pendekatan Pengeluaran (Consumption Approach)

Metode ini dihitung dengan menambahkan semua biaya untuk berbagai kelompok pembeli di masyarakat. Secara matematis:

$$
\mathrm{Y}=\mathrm{C}+\mathrm{I}+\mathrm{G}+(\mathrm{X}-\mathrm{M})
$$

dimana:

$\mathrm{NI}=\mathrm{PDB}($ Produk Domestik Bruto)

$\mathrm{Y} \quad=\mathrm{PDB}$ (Pendapatan Domestik Bruto)

$\mathrm{C}=$ Pengeluaran Rumah tangga konsumen untuk konsumsi

I $=$ Pengeluaran rumah tangga perusahaan untuk investasi

$\mathrm{G}=$ Pengeluaran rumah tangga pemerintah

$(\mathrm{X}-\mathrm{M})=$ Ekspor netto atau pengeluaran rumah tangga luar negeri

Untuk menghindari penghitungan ganda, hanya hitung nilai perdagangan produk jadi.

\section{Ekspor}

Ekspor memiliki pengertian "arus keluar sejumlah barang dan jasa dari suatu negara ke pasar internasional”. Ekspor bisa terjadi jika sudah cukupnya kebutuhan akan barang-barang/jasa tertentu di dalam negeri atapun baik produk/jasa tadi berkompetitif dalam kualitas / harga dengan produk yang satu jenis di dalam pasar internasional. Ekspor akan memberikan pendapatan nasional, valuta asing yang relevan untuk membiayai impor dan pembangunan negara yang dibutuhkan.

Michael P. Todaro (2013:74) berasumsi bahwa kegiatan perdagangan ekspor internasional untuk mempromosikan pertumbuhan permintaan domestik untuk 
mendorong industri-industri besar tumbuh, dengan struktur politik yang stabil dan sistem sosial yang fleksibel. Dengan kata lain, ekspor mencerminkan kegiatan perdagangan yang dapat memberikan pertumbuhan yang dinamis untuk peningkatan perdagangan internasional, sehingga cenderung untuk membantu mencapai kemajuan ekonomi negara-negara berkembang seperti dengan negara-negara maju.

\section{Pengeluaran Pemerintah}

Pengeluaran pemerintah adalah nilai perbelanjaan pemerintah yang digunakan untuk kepentingan masyarakat. pengeluaran pemerintah tercermin dalam kebijakan pemerintah. "Apabila pemerintah telah menetapkan suatu kebijakan untuk membeli barang dan jasa, pengeluaran pemerintah mencerminkan biaya yang harus dikeluarkan oleh pemerintah untuk melaksanakan kebijakan tersebut" (Gujarati, 2013).

Dua orang yang mengembangkan teori dari belanja pemerintah adalah Peacock dan Wiseman. Pandangan mereka masyarakat tidak suka membayar pajak dan peningkatan belanja pemerintah, tetapi pemerintah berusaha untuk meningkatkan pengeluaran pemerintah. Peacock dan Wiseman memiliki dasar teori masyarakat punya tingkat toleransi pajak sendiri, yang artinya mereka bisa memahami kebutuhan pemerintah atas nilai pungutan pajak. Jadi orang-orang tahu bahwa pemerintah harus memiliki tingkat tertentu untuk orang-orang yang membayar pajak guna untuk mendanai kegiatan keuangan pemerintah. Ini adalah hambatan yang dapat diterima oleh pemerintah untuk tidak sewenang-wenang menaikkan pemungutan pajak.

\section{Angkatan Kerja}

Menurut Lewis, yang menempatkan teorinya tentang masalah tenaga kerja, yaitu: 'kelebihan pekerja merupakan kesempatan dan bukan masalah'. Kelebihan pekerja di sektor ini akan memberikan kontribusi terhadap pertumbuhan dan menyediakan output pekerja di sektor lain.

Selain itu, Lewis menunjukkan bahwa ada dua wilayah di negara-negara berkembang, yaitu ekonomi industri modern dan industri tradisional. Bentuk-bentuk sektor tradisional bukan pertanian pedesaan saja (pedagang kaki lima, pengecer, pedagang angkringan) sektor informal perkotaan termasuk dalam industri tradisional. Sektor informal dapat menyerap kelebihan tenaga kerja, tenaga kerja yang ada dalam proses industrialisasi yang disebut katup pengaman ketenagakerjaan. Sektor informal 
menyerap kelebihan ke sektor industri modern, sehingga tingkat upah pedesaan di beberapa titik akan meningkat. Kenaikan upah tidak melebihi pasokan pekerja jadi masalah tidak terjadi dalam pertumbuhan ekonomi sehingga mengurangi kesenjangan pendapatan antara daerah pedesaan dan perkotaan. "Sebaliknya kelebihan pekerja justru merupakan modal untuk mengakumulasi pendapatan, dengan asumsi perpindahan tenaga kerja dari sektor tradisional ke sektor modern berjalan lancar dan perpindahan tersebut tidak pernah menjadi terlalu banyak". (Todaro, 2013:59).

\section{METODE PENELITIAN}

\section{Populasi dan Sampel}

Populasi yang diambil oleh peneliti adalah ekspor, pengeluaran pemerintah dan angkatan kerja pada tahun 2008-2017. Dengan teknik sampling jenuh, sampel dalam penelitian ini adalah ekspor, pengeluaran pemerintah dan angkatan kerja pada tahun 2008-2017.

\section{Variabel Penelitian dan Cara Pengkuran}

1. Variabel penelitian

a. Variabel Bebas/Variabel Independen (X)

variabel independen $(\mathrm{X})$ dari penelitian ini adalah ekspor $\left(\mathrm{X}_{1}\right)$, belanja $\left(\mathrm{X}_{2}\right)$ dan tenaga kerja $\left(\mathrm{X}_{3}\right)$.

a. Variabel Terikat/Variabel Dependen (Y)

Dalam penelitian ini, variabel dependen adalah pertumbuhan ekonomi (Y).

2. Cara Pengukuran

Pengukuran variabel yang digunakan oleh penulis adalah dengan menggunakan observasi dan dokumentasi. Observasi dan dokumentasi digunakan untuk mengetahui pengaruh pengeluaran pemerintah terhadap pertumbuhan ekonomi di Tulungagung, dan untuk menentukan efektivitas dari angkatan kerja dalam pertumbuhan ekonomi di Tulungagung, serta mengetahui pengaruh ekspor terhadap pertumbuhan ekonomi di Tulungagung.

\section{Metode Pengumpulan Data}

Data yang digunakan dalam penelitian ini adalah data sekunder dalam bentuk 'time series" yang sifatnya kuantitatif dalam bentuk angka dan sumber daya data yang 
diperoleh dari Badan Pusat (BPS) Tulungagung, Bank Indonesia, dan data pendukung lainnya untuk melaporkan statistik yang diperoleh dari jurnal, buku, penelitian lama.

\section{Metode Analisis Data}

Model "Ordinary Least Square" (OLS) adalah metode analisis data yang digunkan dalam menganalisis dampak dari indikator ekonomi makro pertumbuhan ekonomi di Tulungagung. OLS digunakan untuk memperoleh perkiraan dan menganslisis untuk dampak variabel independen terhadap variabel dependen. "Metode OLS dipilih karena merupakan salah satu metode sederhana dengan analisis regresi yang kuat dan populer, dengan asumsi-asumsi tertentu" (Gujarati, 2013:102).

1. Model Analisis Linier Berganda

Dalam menggunakan langkah yang menentukan regresi linier diambil dengan langkah-langkah uji hipotesis regresi:

$$
Y=\alpha+\beta_{1} X_{1}+\beta_{2} X_{2}+\beta_{3} X_{3}+e
$$

Dimana:

$\mathrm{Y}=$ Pertumbuhan Ekonomi

$\alpha \quad=$ Konstanta

$\beta_{1} \quad=$ Koefisien $X_{1}$

$\beta_{2} \quad=$ Koefisien $X_{2}$

$\beta_{3}=$ Koefisien $X_{3}$

$\mathrm{X}_{1}=$ Variabel ekspor

$\mathrm{X}_{2}=$ Variabel pengeluaran pemerintah

$\mathrm{X}_{3}=$ Variabel angkatan kerja yang bekerja

$\mathrm{e} \quad=$ Error term

2. Analisis Koefisien Determinasi (R-Square $/ \mathrm{R}^{2}$ )

Untuk koefisien determinasi $\left(\mathrm{R}^{2}\right)$ variabel dependen digunakan untuk mengukur kontribusi setiap variabel independen. Jika $\left(\mathrm{R}^{2}\right)$ yang diperoleh mendekati 1 (satu), dapat dikatakan untuk meningkatkan model yang menggambarkan hubungan antara variabel independen terhadap variabel dependen. Di sisi lain, $\left(\mathrm{R}^{2}\right)$ berpengaruh lemah dari variabel independen terhadap variabel dependen, jika $\mathrm{R}^{2}$ ini telah mendekati 0 (nol).

3. Uji Hipotesis 
a. Pengujian Parsial (Uji t)

Kegunaan Uji t disini adalah untuk memberi bukti mengenai pengaruh parsial yang signifikan antara aspek motivasi kerja terhadap kinerja karyawan. Kriterianya sebagai berikut:

- Jika nilai signifikan $\mathrm{t}$ hitung $>\mathrm{t}$ tabel, maka variabel terikat terpengaruh signifikan oleh variabel bebas.

- Jika nilai signifikan $\mathrm{t}_{\text {hitung }}<\mathrm{t}_{\text {tabel}}$, maka variabel terikat tidak terpengaruh signifikan oleh variabel bebas.

b. Pengaruh Secara Simultan (Uji F)

Uji hipotesis simultan adalah dampak yang signifikan terhadap variabel dependen (Y) digunakan untuk menentukan variabel independen (X). kriteria keputusan, yaitu:

- Jika $\mathrm{F}_{\text {hitung }}>\mathrm{F}$ tabel, maka variabel terikat secara simultan terpengaruh signifikan oleh variabel bebas.

- Jika nilai $\mathrm{F}$ hitung $<\mathrm{F}$ tabel, maka variabel terikat secara simultan tidak terpengaruh signifikan oleh variabel bebas.

\section{Uji Asumsi Klasik}

a. Uji Normalitas

Tujuan uji normalitas untuk menguji apakah distribusi normal dimiliki dalam model regresi, variabel penganggu atau residul. Uji statistik non-parametrik Kolmogrov-Smirnov (K-S) digunkan dengan membuat hipotesis :

Ho : data residual berdistribusi normal

Ha : data residual tidak berdistribusi normal

Pengujian yang dapat menunjukkan data normal yang diperoleh apabila nilai signifikasinya adalah $>0,01$.

b. Uji Multikolinearitas

Uji multikolinearitas bertujuan untuk menguji apakah korelasi ditemukan pada model regresi antar setiap variabel independen (independent) dengan kriteria sebagai berikut:

a. Mempunyai angka Tolerance $\leq 0,10$

b. Mempunyai nilai VIF $\geq 10$ 
c. Uji Heteroskedastisitas

Uji heteroskedastisitas bertujuan menguji ketidaksamaan variance dalam model regresi dari berbagai pengamatan. Untuk mendeteksi Heteroskedastisitas adalah dengan melihat Grafik Plot, hal itu tidak terjadi Heteroskedastisitas jika tidak ada pola yang jelas serta titik-titik yang tersebar di atas dan di bawah angka 0 pada sumbu Y.

\section{HASIL PENELITIAN}

\section{Regresi Linier}

Dari hasil analisis regresi linier berganda dengan metode OLS, terdapat suatu bentuk model persamaan untuk Pengaruh Ekspor, Pengeluaran Pemerintah, dan Angkatan Kerja yang Bekerja Terhadap Pertumbuhan Ekonomi Kabupaten Tulungagung.

Tabel 2. Analisis Regresi Ekspor, Pengeluaran Pemerintah dan Angkatan Kerja yang Bekerja di Kabupaten Tulungagung

\begin{tabular}{|l|r|r|r|r|r|r|r|}
\hline \multirow{2}{*}{ Model } & \multicolumn{2}{|c|}{$\begin{array}{c}\text { Coefficients } \\
\text { Unstandardized } \\
\text { Coefficients }\end{array}$} & $\begin{array}{c}\text { Standardized } \\
\text { Coefficients }\end{array}$ & $\mathrm{t}$ & Sig. & \multicolumn{2}{|c|}{$\begin{array}{c}\text { Collinearity } \\
\text { Statistics }\end{array}$} \\
\cline { 2 - 8 } & $\mathrm{B}$ & Std. Error & Beta & & & Tolerance & VIF \\
\cline { 2 - 8 } & 16204,516 & 105495,412 & &, 154 &, 883 & & \\
(Constant) & 83,643 & 379,498 &, 026 &, 220 &, 833 &, 505 & 1,979 \\
Ekspor & 21,397 & 3,098 &, 855 & 6,906 &, 000 &, 464 & 2,157 \\
Pengeluaran Pemerintah &, 038 &, 022 &, 175 & 1,736 &, 133 &, 697 & 1,434 \\
\hline
\end{tabular}

a. Dependent Variable: Pertumbuhan Ekonomi

Sumber: Data diolah peneliti, (2019).

Analisis regresi linier berganda diperoleh sesuai dengan tabel di atas:

$Y=16204,516+83,643 X_{1}+21,397 X_{2}+0,038 X_{3}$

Hasil persamaan memiliki dampak positif pada variabel ekspor, pengeluaran pemerintah dan angkatan kerja yang bekerja terhadap pertumbuhan ekonomi di Tulungagung. 


\section{Koefisien Determinasi (R-Square/ $\mathbf{R}^{\mathbf{2}}$ )}

Tabel 3. Hasil Pengujian Koefisien Determinasi

\begin{tabular}{|c|c|c|c|c|c|}
\hline \multicolumn{6}{|c|}{ Model Summary ${ }^{\mathbf{b}}$} \\
\hline Model & $\mathrm{R}$ & R Square & Adjusted R Square & $\begin{array}{l}\text { Std. Error of the } \\
\text { Estimate }\end{array}$ & Durbin-Watson \\
\hline 1 &, $978^{a}$ & 957 & 936 & 14421,42017 & 1,591 \\
\hline
\end{tabular}

a. Predictors: (Constant), AK yang Bekerja, Ekspor, Pengeluaran Pemerintah

b. Dependent Variable: Pertumbuhan Ekonomi

Sumber: Data diolah peneliti, (2019).

Berdasarkan tabel, untuk mendapatkan nilai $\mathrm{R}^{2}$ sejumlah 0,957. Ini bersama-sama menunjukkan bahwa variabel independen dapat menjelaskan pada variabel dependen sebesar 95,7\%. Sisa 4,3\% dijelaskan oleh variabel lain dari model eksternal.

\section{Uji Hipotesis}

1. Pengujian secara Parsial (Uji t)

a. Variabel Ekspor

Dari hasil perhitungan didapatkan nilai $\mathrm{t}$ hitung sebesar $0,220<\mathrm{t}$ tabel 2,447 dengan nilai signifikan $0,000<0,833$. Maka dapat dikatakan bahwa ekspor berpengaruh tidak signifikan terhadap pertumbuhan ekonomi.

b. Variabel Pengeluaran Pemerintah

Dari hasil perhitungan output di atas dapat disimpulkan bahwa nilai $\mathrm{t}$ hitung sebesar 6,906 > nilai $\mathrm{t}$ tabel 2,447 dengan nilai signifikan 0,000>0,05. Maka dapat dikatakan bahwa variabel pengeluaran pemerintah pengaruh signifikan terhadap pertumbuhan ekonomi.

c. Variabel Angkatan Kerja yang Bekerja

Dari hasil perhitungan output di atas dapat disimpulkan bahwa nilai $\mathrm{t}$ hitung sebesar $1,736<$ nilai $t$ tabel 2,447 dengan nilai signifikan $0,133<0,05$. Maka dapat dikatakan bahwa variabel angakatan kerja yang bekerja pengaruh tidak signifikan terhadap pertumbuhan ekonomi.

2. Pengujian secara Simultan (Uji F) 
Tabel 4. Hasil Uji secara Simultan (Uji F)

ANOVA $^{\mathrm{a}}$

\begin{tabular}{|c|c|c|c|c|c|c|}
\hline \multicolumn{2}{|c|}{ Model } & Sum of Squares & df & Mean Square & $F$ & Sig. \\
\hline \multirow{3}{*}{1} & Regression & 130879468413,797 & 3 & 43626489471,266 & 361,784 &, $000^{\mathrm{b}}$ \\
\hline & Residual & 2049978501,155 & 17 & 120586970,656 & & \\
\hline & Total & 132929446914,952 & 20 & & & \\
\hline
\end{tabular}

a. Dependent Variable: Pertumbuhan Ekonomi

b. Predictors: (Constant), Angkatan Kerja, Pengeluaran Pemerintah, Ekspor

Sumber : Data primer yang diolah peneliti (2019)

Berdasarkan hasil analisis model regresi pada tabel di atas dapat diketahui bahwa $F_{\text {hitung }}>F_{\text {tabel }}(361,784>3,20)$, maka Ho ditolak (Ha diterima). Artinya bahwa secara bersama-sama variabel $\mathrm{X}_{1}$ (Ekspor), $\mathrm{X}_{2}$ (Pengeluaran Pemerintah), dan $\mathrm{X}_{3}$ (Angkata Kerja yang Bekerja) berpengaruh secara signifikan terhadap Pertumbuhan Ekonomi Kabupaten Tulungagung pada $\alpha=5 \%$.

\section{Uji Asumsi Klasik}

Adapun hasil uji penyimpangan asumsi klasik pada penelitian ini adalah sebagai berikut:

1. Uji Normalitas

Uji normalitas bertujuan untuk menguji apakah ada distribusi normal atau tidak normal yang terdapat di dalam model regresi variabel pengganggu atau residual. Berdasarkan hasil uji, dapat disimpulkan bahwa titik penyebaran sudut data yang terdistribusi normal.

2. Uji Multikolinearitas

Hasil dari tabel 2 nilai VIF dari masing-masing variabel bebas kurang dari 10 . Artinya tidak terjadi multikolinieritas pada model regresi.

3. Uji Autokorelasi

Dengan jumlah sampel dan jumlah variabel independent tertentu, diperoleh nilai kritis $d L$ dan $d U$ dalam distribusi Durbin Watson untuk berbagai nilai $\alpha$ yaitu nilai $d L=1,026$ dan $d U=1,669$. Dari hasil hitung SPSS diperoleh nilai D-W hitung yaitu sebesar 1.591, angka ini terletak di antara -2 dan +2 . Dari pengamatan ini dapat disimpulkan, bahwa tidak terjadi autokorelasi positif maupun autokorelasi negatif dalam penelitian ini. 


\section{Uji Heteroskesdastisitas}

Berdasarkan hasil uji menunjukkan tidak terbentuk pola tertentu, yang berarti bahwa tidak ada masalah asumsi heterokedastisitas .

\section{Pembahasan}

Berikut ini didasarkan pada analisis data yang dapat digambarkan dalam deskripsi:

1. Pengaruh ekspor terhadap pertumbuhan ekonomi di Tulungagung

Ekspor memiliki pengertian "arus keluar sejumlah barang dan jasa dari suatu negara ke pasar internasional”. Ekspor bisa terjadi jika sudah cukupnya kebutuhan akan barang-barang/jasa tertentu di dalam negeri atapun baik produk/jasa tadi berkompetitif dalam kualitas / harga dengan produk yang satu jenis di dalam pasar internasional. Ekspor akan memberikan pendapatan nasional, valuta asing yang relevan untuk membiayai impor dan pembangunan negara yang dibutuhkan.

Dalam penelitian ini, pertumbuhan ekonomi di Kabupaten Tulungagung. terpengaruh positif tidak signifikan oleh ekspor. Setiap kenaikan Rp 1 milyar jumlah ekspor mempengaruhi meningkatnya angka pertumbuhan ekonomi sebesar Rp 83,643 milyar dengan asumsi ceteris paribus.

Sedangkan dari hasil analisa metode estimasi dapat diketahui bahwa $t_{\text {hitung }}<$ $t_{\text {tabel }}(0.220<2.447)$. Dengan demikian $H_{o}$ diterima $\left(H_{a}\right.$ ditolak $)$. Artinya Pertumbuhan Ekonomi Kabupaten Tulungagung (Y) pada $\alpha=5 \%$ terpengaruh tidak signifikan oleh ekspor $\left(\mathrm{X}_{1}\right)$.

2. Pengaruh pengeluaran pemerintah terhadap pertumbuhan ekonomi di Tulungagung

Melalui pembayaran pajak, masyarakat secara tidak langsung memiliki dan menjadi kuasa pemerintah mengenai penggunaan sumber daya dari aspek pengeluaran pemerintah.

Dalam penelitian ini, pertumbuhan ekonomi di Kabupaten Tulungagung terpengaruh positif signifikan oleh pengeluaran pemerintah. Di setiap naiknya Rp 1 milyar jumlah pengeluaran pemerintah berpengaruh terhadap naiknya pertumbuhan ekonomi sebesar Rp 21,397 milyar dengan asumsi ceteris paribus.

Sedangkan berdasarkan hasil analisa metode estimasi dapat diketahui bahwa $t_{\text {hitung }}>t_{\text {tabel }}(6,906>2,447)$. Dengan demikian $H_{o}$ ditolak $\left(H_{a}\right.$ diterima $)$. Artinya 
Pertumbuhan Ekonomi Kabupaten Tulungagung $(\mathrm{Y})$ pada $\alpha=5 \%$. $\left(\mathrm{X}_{2}\right)$ terpengaruh signifikan oleh Pengeluaran Pemerintah

3. Pengaruh angkatan kerja yang bekerja terhadap pertumbuhan ekonomi di Tulungagung

Orang yang tidak memiliki pekerjaan, tidak bekerja pula, dan tenaga kerja yang tidak sedang memiliki pekerjaan adalah istilah sederhana dari angkatan kerja, seperti contoh: orang-orang yang sedang sekolah, mengurus rumah tangga serta mendapat pendapatan tapi bukan imbalan langsung atas jasa atas kerjanya (pensiunan, penderita cacat yang independen).

Dalam penelitian ini, pertumbuhan ekonomi di Kabupaten Tulungagung terpengaruh positif signifikan oleh angkatan kerja yang bekerja. Pada setiap peningkatan 1 jiwa angkatan kerja yang bekerja berdampak naiknya pertumbuhan ekonomi sebesar Rp 0,038 milyar dengan asumsi ceteris paribus.

Namun dari hasil analisa metode estimasi dapat diketahui bahwa $t_{\text {hitung }}>t_{\text {tabel }}$ $(1,736<2,447)$. Dengan demikian Ho ditolak (Ha diterima). Artinya Pertumbuhan Ekonomi Kabupaten Tulungagung (Y) pada $\alpha=5 \%$ terpengaruh tidak signifikan oleh angkatan kerja yang bekerja $\left(\mathrm{X}_{3}\right)$.

Sedangkan untuk uji F-Statistik ini untuk pengujian signifikansi pengaruh variabel independen secara bebarengan terhadap nilai variabel dependen. Uji ini melihat seberapa besar pengaruh variabel $\mathrm{X}_{1}$ (Ekspor), $\mathrm{X}_{2}$ (Pengeluaran Pemerintah), dan $\mathrm{X}_{3}$ (Angkatan Kerja yang bekerja) secara bersama-sama terhadap variabel Y (Pertumbuhan Ekonomi Kabupaten Tulungagung).

Berdasarkan hasil analisis model regresi pada tabel di atas dapat diketahui bahwa $F_{\text {hitung }}>F_{\text {tabel }}(44,911>4,76)$, maka Ho ditolak (Ha diterima). Artinya bahwa Pertumbuhan Ekonomi Kabupaten Tulungagung pada $\alpha=5 \%$ terpengaruh secara signifikan oleh variabel $X_{1}$ (Ekspor), $X_{2}$ (Pengeluaran Pemerintah), dan $X_{3}$ (Angkatan Kerja yang Bekerja) secara bersamaan. 


\section{KESIMPULAN DAN SARAN}

\section{Kesimpulan}

Berdasarkan hasil penelitian dan pembahasan, maka kesimpulan yang di dapat adalah:

1. Pertumbuhan ekonomi di Kabupaten Tulungagung terpengaruh positif tidak signifikan oleh ekspor, pada setiap peningkatan $\mathrm{Rp} 1$ milyar jumlah ekspor berdampak pada naiknya pertumbuhan ekonomi sebesar Rp 83,643 milyar dengan asumsi ceteris paribus.

2. Pertumbuhan ekonomi di Kabupaten Tulungagung terpengaruh positif signifikan oleh pengeluaran pemerintah. Disetiap naiknya Rp 1 milyar jumlah pengeluaran pemerintah berpengaruh terhadap naiknya pertumbuhan ekonomi sebesar Rp 21,397 milyar dengan asumsi ceteris paribus.

3. Pertumbuhan ekonomi di Kabupaten Tulungagung terpengaruh positif signifikan oleh angkatan kerja yang bekerja. Pada setiap peningkatan 1 jiwa angkatan kerja yang bekerja berdampak naiknya pertumbuhan ekonomi sebesar Rp 0,038 milyar dengan asumsi ceteris paribus.

\section{Saran}

Beberapa saran akan penulis berikan sehubungan dengan penelitiaan ini adalah:

1. Untuk meningkatkan pertumbuhan ekonomi Kabupaten Tulungagung, maka indikator makro ekonomi harus ditingkatkan.

2. Untuk mendukung pertumbuhan ekspor, lembaga keuangan pemerintah maupun swasta harus dapat menyalurkan kredit ke sektor-sektor riil yang tepat, terutama sektor pertanian, industri kecil dan menengah, serta sektor-sektor lain yang berorientasi pada ekspor.

3. Untuk meningkatkan kualitas angkatan kerja, lembaga pemerintah maupun swasta harus membekali pelatihan dan pengalaman untuk semua angkatan kerja agar hasil produksinya lebih produktif.

\section{DAFTAR PUSTAKA}

Arikunto, Suharsimi. (2016), “Prosedur Penelitian Suatu Pendekatan Praktik”. Jakarta: Rineka Cipta.

Arsyad, Lincolin. (2014), “Ekonomi Pembangunan”, Yogyakarta: STIE YKPN, 
Asion, Corel. (2014), "Pengaruh Pengeluaran Pemerintah, Penanaman Modal Asing dan Tenaga Kerja terhadap Pertumbuhan Ekonomi”, Medan: Universitas Sumatera Utara.

Boediono, (2014), “Teori Pertumbuhan Ekonomi”, Yogyakarta: BPFE UGM.

Dewandaru bothy, purnamaningsih nining. (2016). Strategi dalam memajukan industri kreatif dan pengembangan ekonomi lokal sebagai daya tarik wisata (study pada kesenian jaranan dikota kediri). EKONIKA, 1(2), 170-187. https://doi.org/http://dx.doi.org/10.30737/ekonika.v1i2.4

Endang Putri Dewi, I. (2019). Pengaruh tenaga Kerja,Migrasi Masuk dan Pembangunan Manusia Terhadap Pertumbuhan Ekonomi Di Indonesia. JKEP, 1(2), 251-262. Retrieved from http://ejournal.unp.ac.id/students/index.php/epb/article/view/6168/3087

Joan Marta, D. Z. P. (2010). Analisis Penyerapan Tenaga Kerja Pada Sektor-Sektor Unggulan Dalam Mendorong Pertumbuhan Ekonomi Di Propinsi Sumatra Barat, 10(2), 1-7. Retrieved from http://ejournal.unp.ac.id/index.php/Economac/article/view/4046/3229

Putra, Yudiarto Perdana, heryanto, B. (2017). Pemetaan kepemilikan badan hukum dan tingkat penggunaan teknologi informasi pada UMKM ( Studi Pada Kelurahan Pojok Kecamatan Mojoroto - Kota Kediri ). EKONIKA, 2(2), 183-197. https://doi.org/http://dx.doi.org/10.30737/ekonika.v2i2.44

Butar-Butar, Candra P. (2014), "Analisis Pengaruh Pengeluaran Pemerintah Kota terhadap Pertumbuhan Ekonomi”. Medan: Universitas Sumatera Utara.

Ferdinand, Augusty. (2016). "Metode Penelitian Manajemen: Pedoman Penelitian untuk Skripsi, Tesis dan Disertasi Ilmu Manajemen”. Semarang: Badan Penerbit Universitas Diponegoro.

Ghozali, Imam. (2015), "Analisis Multivariate dengan Program SPSS”, Semarang: Universitas Diponegoro

Gujarati, Damodar. (2013), “Ekonometri Dasar”. Terjemahan: Sumarno Zain, Jakarta: Erlangga.

Helmi, Syafrizzal Situmorang dan Lufti, Muslich. (2011), “Analisis Data”, Medan: USU Press.

Mangkoesoebroto, Guritno. (2013), "Ekonomi Publik”, Yogyakarta: BPFE UGM.

Mohdari, (2013), "Bahan Ajar Ekonomi Makro", Jakarta: In Media.

Nasution, Syahrir Hakim dan Rakhmat Sumanjaya, (2015), "Teori Ekonomi Makro", Medan: USU Press.

Nensy. (2015), "Analisis Faktor-Faktor yang Mempengaruhi Pertumbuhan Ekonomi". Medan: Universitas Sumatera Utara.

Nur Baeti. (2013), "Pengaruh Pengangguran, Pertumbuhan Ekonomi, dan Pengeluaran Pemerintah terhadap Pembangunan Manusia Kabupaten/Kota di Provinsi Jawa Timur tahun 2016-2017”. Economics Development Analysis Journal, Vol.2

Rahardja, Prathama dan Mandala Manurung, (2011), "Teori Makro Ekonomi Suatu Pengantar", Jakarta: Lembaga Penerbit Fakultas Ekonomi Universitas Indonesia.

Nizar, Chairul, dan Abubakar Hamzah. (2013), "Pengaruh Investasi dan Tenaga Kerja terhadap Pertumbuhan Ekonomi serta hubungannya terhadap Tingkat Kemiskinan di Indonesia “. Vol.1, No.2 
Sugiyono. (2014), “Metode Penelitian Kuantitatif, Kualitatif dan $R \& D$ ”, Bandung: CV. Alfabeta.

Sukirno, Sadono. (2014), "Makro Ekonomi Modern", Jakarta: Rajawali Press. . (2014), "Makroekonomi Teori Penganta"r, Jakarta: PT Raja Grafindo Persada.

Tarigan, Robinson. (2015), "Ekonomi Regional: Teori Pertumbuhan Ekonomi Wilayah". Jakarta: Bumi Aksara.

Todaro, Michael P, (2013), "Pembangunan Ekonomi di Dunia Ketiga”, Jakarta: Erlangga.

Umar, Husein. (2012). "Pemasaran dan Perilaku Konsumen". Jakarta: PT. Gramedia Pustaka Utama.

Zainal, A. (2017). "Faktor-faktor yang Mempengaruhi Permintaan Ekspor". Jakarta: Fakultas Ekonomi Universitas Indonesia. 